\title{
Applying Theory Y to Library Management
}

Theory $Y$ is described as a desirable and widely accepted philosophy of personnel management. A review of library literature shows that its acceptance by librarians is relatively slight and that it is invariably considered to be the equivalent of participative management. The author disagrees with this comparison and believes that participative management has little effect upon the motivations associated with Theory $Y$. Instead, the author discusses several measures which he feels from experience can provide Theory $Y$ benefits in library operations.

$\mathrm{T}$ sonnel management to denote a liberalized type of administrative philosophy based upon a belief that employees are responsible workers more likely to be influenced by their own internal motivations than by the external threats and inducements of management. Because of its importance, library administrators need to be aware of this theory and of its possible adaptation to library operations. Therefore, this paper is intended to review the principles of the Theory $\mathrm{Y}$ approach, report upon its coverage in library literature, distinguish between the concepts of Theory $\mathrm{Y}$ and participative management, and, finally, discuss how Theory Y's application in a small academic library recommends its use for library operations in general.

\section{McGregor and Theory Y}

In the late 1950s, McGregor revolutionized management theory by incorporating into it Maslow's view that man

Donald J. Morton is library director, University of Massachusetts Medical School, Worcester. is subject to a range of motivations that can affect his behavior. ${ }^{1}$ These desires extend from the lowest-level or physiological needs through the safety, social, and esteem wants to the highest-level motivators, which Maslow termed "selfactualization" to represent man's need to be what he feels he must be. ${ }^{2}$ McGregor believed traditional carrot-stick methods of stimulating production are effective only when man's lower-level needs (food, shelter, clothing, security, etc.) are inadequately met and, as an illustration, noted that man normally has ample air to breathe and thus would not be expected to work harder merely to obtain more air. Once the basic needs are satisfied, people become motivated primarily by their desire for esteem (self-respect and reputation) and selfactualization. McGregor called the conventional managerial philosophy Theory $\mathrm{X}$ and his new interpretation Theory $\mathrm{Y}$, thereby polarizing the science of management into two easy-to-grasp reference points. The significance of these ideas has so influenced the field of administration that much of its subsequent literature has dealt with the rami- 
fications of McGregor's simplified approach. Reider recently typified this attitude by stating that McGregor's "insights regarding managerial assumptions about people are timeless" and must be considered the starting point for conducting a performance review. ${ }^{3}$ Drucker credits McGregor's The Human Side of Enterprise with being "the most widely read and quoted" of books about modern personnel management. ${ }^{4}$

A brief description of a Theory Y environment is that, consistent with maintaining the objectives of an organization, an employee is given the maximum opportunity for self-determination and is subjected to the minimum amount of obvious authority, which means, in current terminology, that he should feel he's doing his thing. His innate desires to be creative, useful, respected, and superior should be encouraged rather than thwarted.

A common misconception with respect to Theory $\mathrm{Y}$ is that it represents a permissive, lax type of administration which coddles employees in the hope that they will respond by wanting to work. On the contrary, it requires the same ultimate authority needed with Theory $\mathrm{X}$ except that such authority should be kept sufficiently remote to preclude intruding upon an employee's pursuit of higher-level goals. Thus Theory Y's administration is more subtle than Theory X's and necessitates careful planning in order to attain the optimum balance between authority and freedom. Similarly, employees under Theory $\mathrm{Y}$ have a more, rather than a less, demanding task than do those under Theory $\mathrm{X}$ because, as Maslow noted, they must replace the comforting security of order and direction with the burden of responsibility and self-discipline. ${ }^{5}$

Drucker used the term "knowledge worker" to describe an employee who, in contrast to a "manual worker," needs the benefits of a formal education to perform his services, adding that the knowledge worker does not produce well if managed under Theory $\mathrm{X} .{ }^{6}$ Thus a good example of Theory $\mathrm{Y}$ in practice may be found in the management of knowledge workers, as typified by a research laboratory where the employer's objective is to discover profitable techniques and products. The highly educated employees may not share these corporate goals but, instead, are motivated to create research which can be published to enhance their professional reputations. Consequently, the objectives of the employer and those of the employees are different but require the same output on the part of the employees. The result is that progress toward increasing the employer's profits is favored by a climate which allows the employees to freely follow their own drives for esteem.

\section{Theory Y in Library Literature}

Because Theory $\mathrm{Y}$ has had such an impact upon the current concepts of management, the author decided to determine whether this approach has been implemented by library administrators and, if so, whether results have been favorable. Therefore, the literature of library management was reviewed in order to establish what recognition has been given to Theory $\mathrm{Y}$ and what use has been made of this concept in the management of library employees.

A number of references to McGregor's Theory $\mathrm{Y}$ were found in library literature. Some were merely reprints or rehashes of papers by professional administrators which had previously appeared in managerial publications and, as they did not stress library operations, were not considered indicative of the thinking in library circles. ${ }^{7}$ There were, however, several articles by librarians in which Theory $\mathrm{Y}$ was recognized and, to varying degrees, recommended for use. 
Kipp, reviewing the literature of management, said that McGregor's philosophy "probably provides the most useable concepts in management literature by librarians." He suggested librarians might benefit from this approach but didn't apply it to specific library procedures.8

Betty Jo Mitchell developed a training program for library assistants who supervised clerical personnel or student assistants. She patterned her program after McGregor by having her trainees read his discussions along with other recent books on administration. The students concluded that Theory $\mathrm{Y}$ in its pure form was not satisfactory but should be modified, as suggested by Morse and Lorsch, to fit the tasks and people involved. This modification was based upon Drucker's opinion that Theory Y works with knowledge workers but Theory $\mathrm{X}$ often is more effective with manual workers. ${ }^{9}$

Robert and Charlene Lee, referring to Theory $\mathrm{Y}$ as "management by participation," said it is "a tough-minded management style-and it works." They encouraged the idea that personnel planning should be concerned with an individual's aspirations and should provide him or her with opportunities for participation and growth. 10

Dickinson cited McGregor and stated that "Libraries ... need to be aware of certain world-wide trends in work theory, according to which meaningful and significant work (attained through participative management) replaces economic rewards as the central institutional incentive." She proposed a sequence of steps which could be followed for changing from a hierarchical to a participative type of management and recommended such an arrangement for activizing the professional staff/11

DeProspo thought that Theory Y requires a move away from "management by control" to one of "management by objectives." $\mathrm{He}$ favored a model in which the active participation of staff and line employees is encouraged and felt that evaluations of personnel should stress goals rather than traits. ${ }^{12}$

Marchant noted that "new theories direct attention towards other sources of motivation besides the economic," basing this opinion upon Maslow's hierarchy of motivations. He believed that participative management is an important means of enabling employees to operate with higher-level motivations, but reported that a literature search found no studies of library staff participation in decision making. After evaluating library situations, he concluded that "active staff development programs and participative management in libraries appear well suited for each other; they ought to be getting together." ${ }^{13}$

The preceding references show that some libraries recognize Theory Y and, furthermore, believe it is typified by participative management. In addition, several other papers were found which did not mention Theory $\mathrm{Y}$ as such but stressed the value of participative management for libraries. ${ }^{14}$ McGregor said that when participative management "grows out of the assumptions of Theory Y," it can provide "ego satisfaction for the subordinate" and "thus affect motivation towards organizational objectives." He believed this satisfaction results from the tackling and solving of problems, the feeling of greater independence and influence, and the increased recognition received from peers and superiors for making worthwhile contributions. $^{15}$ Consequently, participative management is related to Theory $\mathrm{Y}$ in that its use helps establish an environment in which ego needs may be fulfilled.

Despite its intrinsic merits, however, it is questionable whether participative management illustrates Theory Y's basic tenet that an employee's self-motivation to pursue his own goals can help satisfy his employer's organizational ob- 
jectives. Any such effect would be remote at best and would be limited to those decisions where an employee's responsibilities and relationships would be so altered as to affect his higher-level motivations.

\section{The Use of Theory Y in a Library}

Consequently, the way to induce Theory $\mathrm{Y}$ management in libraries is to focus not upon participatory management, which, though desirable in its own right, can give only random Theory $\mathrm{Y}$ benefits, but, instead, upon the characteristics of each employee's position. In this regard, the author has worked with a variety of personnel during the development of a new library and, based upon these experiences, suggests that some of the more effective policies for eliciting Theory $\mathrm{Y}$ motivations include providing employees with (1) definite and unique responsibilities; (2) a short administrative chain of command; (3) adequate means to exhibit productivity to others; (4) freedom from fear of failure; and (5) opportunities to merge self-actualization with normal responsibilities.

Probably the most important of these policies is the assigning to each employee of a clear set of responsibilities which do not overlap those of anyone else because, without this basic arrangement, there can be little hope of having Theory $\mathrm{Y}$ conditions. Unless a person can unmistakably identify with the fruits of his labor, there is little chance that any of his higher-level needs will directly motivate his productivity. Any sharing of responsibilities between employees dulls this motivation and increases the opportunities for dissatisfaction. In practice, this means dividing responsibilities between available personnel rather than assigning more than one person to an area. For example, if two catalogers are employed, they should not both routinely share all of the responsibilities but, rather, should each be given a discrete and approximately equal portion of the load according to some criterion such as subject or type of material. Within a designated area of responsibility, an employee should be free to determine how to manage his own operations as long as his output conforms with organizational goals and his procedures don't conflict with operations in other areas.

In addition, the lines of authority should be kept as short as possible in order to maximize the sole responsibility of each employee. Using the above example of two catalogers, it would be preferable to have each one answering directly to the highest feasible level of administration rather than having one cataloger answering to the other because, in the latter case, both catalogers would be responsible for the duties of the subordinate one. Besides this direct Theory $\mathrm{Y}$ benefit, shorter organizational lines have the indirect value of increasing lateral communication between employees and the practical merit of reducing misunderstandings by decreasing the number of times an idea must be relayed. According to Townsend, each extra "level of management lowers communication effectiveness within the organization by about 25 percent." 16

Another characteristic of a Theory $\mathrm{Y}$ position is that each person's performance must be visible enough to be capable of earning respect from others. Hence, to stimulate the esteem needs for respect and admiration, each employee's productivity should be subject to the scrutiny of other employees. An acquisitions librarian might be judged by the quality of new books, a cataloger by the arrangement and accessibility of the collection, and a public services librarian by the reactions of the library users to the available services. Then, each person's output would be self-regulated by the motivation to be respected, and the administration could watch from a nonintrusive distance for signs that adjustments were needed. 
A self-regulating operation, however, must be free to alter its procedures or else an employee may not accept responsibility for his output. This means that management should exhibit confidence in an employee to the extent that failures will not be used as a basis for embarrassment or punishment but, instead, will be evaluated as demonstrating an employee's willingness to improve operations by taking calculated risks. Similarly, any criticisms made should avoid placing an employee on the defensive, as Gibb pointed out in his excellent discussion on the subject. Penalizing errors and inciting defensiveness not only will discourage initiative but also will promote the concealment of mistakes, thereby hindering communication and providing a distorted view of operations. ${ }^{17}$

Finally, the ultimate expression of Theory Y management may be realized if there are opportunities for an employee to identify his responsibilities with his desire for self-actualization, Maslow's highest level of motivation. In Townsend's words, this means having the employee "enjoy his work so much he comes in on Saturday instead of playing golf or cutting grass," 18 which, in a librarian's terms, might signify an employee who experiments with his procedures and presents papers on the results to professional colleagues. Measures which arouse these tendencies include the previously mentioned freedom to make mistakes plus the encouragement and financial support of the administration to join organizations and attend meetings. In this type of atmosphere, employees may become so absorbed in their career interests that their tendencies toward self-actualization will be expressed within the framework of normal occupational duties.

A distinction should be made between the factors described above which di- rectly affect employee higher-level motivations and indirect factors which act instead to create a Theory Y environment. Such indirect factors are important because, although they do not affect productivity in an obvious manner, their presence encourages employees to feel trusted, appreciated, and responsible, and thus to be more receptive to the stimuli of Theory Y motivators. Examples of these environmental influences include (1) favoring intercommunication between all employees; (2) delegating the maximum feasible amount of the organization's decision making process, as in participative management; (3) cultivating feelings of fair play; and (4) showing appreciation and sensitivity for employee efforts, achievements, and problems.

\section{ConCLusion}

In conclusion, the author believes that libraries are suitable institutions for the application of Theory Y because of several reasons. First, librarians are by nature knowledge workers who have professional interests and thus are especially susceptible to motivations based upon desires for esteem and self-actualization. Next, the attitudes and duties of librarians are usually oriented toward providing information desired by patrons rather than toward obtaining financial returns; as a result, higher-level motivations may often be satisfied through the idealistic performance of services. Finally, libraries can usually be organized so that each worker has a rewarding, interesting, and unique area of responsibility, thereby stimulating the fulfillment of ego motivators. Consequently, it is recommended that library administrators seriously consider adopting measures that favor Theory $\mathrm{Y}$ management in order to promote employee satisfaction while simultaneously improving employee performance levels. 


\section{REFERENCES}

1. Douglas M. McGregor, "The Human Side of Enterprise," in his Leadership and Motivation (Cambridge, Mass.: MIT Press, 1966), p.3-20, first published in Adventures in Thought and Action, Proceedings of the Fifth Anniversary Convocation of the School of Industrial Management, Massachusetts Institute of Technology, Cambridge, April 9, 1957 (Cambridge, Mass.: MIT School of Industrial Management, 1957); Douglas M. McGregor, The $\mathrm{Hu}$ man Side of Enterprise (New York: McGraw-Hill, 1960).

2. Abraham H. Maslow, Motivation and Personality ( $2 \mathrm{~d}$ ed.; New York: Harper, $1970)$, p. $35-58$.

3. George A. Reider, "Performance Review -A Mixed Bag," Harvard Business Review 51:61-67 (July-Aug. 1973).

4. Peter Drucker, Management (New York: Harper, 1974), p.231.

5. Abraham H. Maslow, Eupsychian Management (Homewood, Ill.: Irwin, 1965), p.2433.

6. Peter Drucker, The Effective Executive (New York: Harper, 1966), p.2-9, 172 74; Peter Drucker, Management (New York: Harper, 1974), p.241.

7. Charles H. Goodman, "Incentives and Motivations for Staff Development," in Elizabeth W. Stone, ed., New Directions in Staff Development (Chicago: American Library Assn., 1971), p.51-57; Charles H. Goodman, "Employee Motivation," Library Trends 20:39-47 (July 1971); Douglas M. McGregor, "The Human Side of Enterprise," in Paul Wasserman and Mary Lee Bundy, eds., Reader in Library Administration (Washington, D.C.; NCR, 1968), p.210-16; Charles Martell, "Which WayTraditional Practice or Modern Theory?" College \& Research Libraries 33:104-12 (March 1972).

8. Laurence Kipp, "Management Literature for Librarians," Library Journal 97:158-60 (Jan. 15, 1972).

9. Betty Jo Mitchell, "In-House Training of Supervisory Library Assistants in a Large Academic Library," College \& Research Libraries 34:114-49 (March 1973); John
J. Morse and Jay W. Lorsch, "Beyond Theory Y," Harvard Business Review 48:61-68 (May-June 1970); Peter Drucker, Management (New York: Harper, 1974), p.241.

10. Robert Lee and Charlene Swarthout Lee, "Personnel Planning for a Library Manpower System," Library Trends 20:19-38 (July 1971).

11. Fidelia Dickinson, "Participative Management: A Left Fielder's View," California Librarian 34:24-33 (April 1973).

12. Ernest D. DeProspo, "Management by Objectives: An Approach to Staff Development," in Elizabeth W. Stone, ed., New Directions in Staff Development (Chicago: American Library Assn., 1971), p.39-47; Ernest D. DeProspo, "Personnel Evaluation as an Impetus to Growth," Library Trends 20:60-70 (July 1971).

.13. Maurice P. Marchant, "Participative Management in Libraries," in Elizabeth W. Stone, ed., New Directions in Staff Development (Chicago: American Library Assn., 1971), p.28-38; Maurice P. Marchant, "Participative Management as Related to Personnel Development," Library Trends 20:48-59 (July 1971).

14. David Kaser, "Modernizing the University Library Structure," College \& Research Libraries 31:227-31 (July 1970); Donald J. Sayer, "Administrative Experiment Tried in Elyria, Ohio," Library Journal 95:1430 (April 15, 1970); Helen L. Norris, "How Far Should Staff Democracy Go?" Library Journal 84:1054-57 (April 1, 1959); Jane G. Flener, "Staff Participation in Management in Large University Libraries," College \& Research Libraries 34:275-79 (July 1973); Richard DeGennaro, "Participative Management or Unionization?" College d Research Libraries 33:173-74 (May 1972).

15. McGregor, The Human Side of Enterprise, p.130-31.

16. Robert Townsend, $U p$ the Organization (New York: Knopf, 1970), p.22.

17. J. R. Gibb, "Defensive Communication," Journal of Communication 11:141-48 (Sept. 1961).

18. Townsend, Up the Organization, p.142. 